\title{
Compensatory growth in Nile tilapia Oreochromis niloticus: feed conversion ratio, size heterogeneity, and proximal composition
}

\author{
Gaspar Román Poot-López ${ }^{1}$, Eucario Gasca-Leyva ${ }^{2 \dagger}$, Carlos González-Salas ${ }^{1}$ \\ Sergio Guillen-Hernández ${ }^{1} \&$ Roger Domínguez-May ${ }^{2}$ \\ ${ }^{1}$ Departamento de Biología Marina, Campus de Ciencias Biológicas y Agropecuarias \\ Universidad Autónoma de Yucatán, Mérida, Yucatán, México \\ ${ }^{2}$ Centro de Investigación y de Estudios Avanzados del Instituto Politécnico Nacional \\ Unidad Mérida, Departamento de Recursos del Mar, Yucatán, México \\ Corresponding author: Eucario Gasca-Leyva (eucario.gasca@ cinvestav.mx)
}

\begin{abstract}
A feeding test was performed to evaluate compensatory growth in the Nile tilapia (Oreochromis niloticus) and to assess changes in feed conversion ratio (FCR), body condition, and carcass composition associated with the imposed feeding strategy. The experiment was carried out under two different stages, restricted (RS) and compensated (CS), with six weeks long each other. Three hundred juveniles of Nile tilapia (average weight of $16.4 \pm 0.2 \mathrm{~g}$ ) were divided into three treatments and one control. The control group was fed to apparent satiation four times a day in both stages. The RS treatments were based on 100\% (RS100), 80\% (RS80), and 60\% (RS60) of a feeding chart, respectively. In the next six weeks, fishes from the CS treatments (CS100, CS80, and CS60) were then fed to apparent satiation four times a day. In the RS, the control group displayed the most considerable weight gained, but with a significant FCR. Nevertheless, in the CS, the previous restricted treatments (RC80 and RC100) showed a compensatory growth, with a smaller FCR than the control group. The restricted-compensated rations did not have a significant effect on the size heterogeneity; when the food is restricted, fish use to moisturize their tissue to compensate for the muscle loss until they receive more food. However, when the food restriction levels are too high, the weight gain, lipid, and protein levels do not recover as they were before. Thus, restricted (marginally) and compensatory feeding strategies provide evidence that growth rates of fishes can be regulated.
\end{abstract}

Keywords: Oreochromis niloticus; tilapia; ration; satiety; feeding chart; growth

\section{INTRODUCTION}

In intensive aquaculture, commercial feed is one of the inputs of the greatest economic impact, since it represents 30 to $60 \%$ of production costs (Guimarães et al., 2008; Borski et al., 2011). Nevertheless, feed ration management can offer growth advantages and decrease its use (Gélineau et al., 1998; Khan et al., 2004; Bureau et al., 2006; Booth et al., 2008). Feed management in fish includes the quality and quantity of protein, ration size, and spatial and temporal supply (Talbot et al., 1999).

Fish growth rate can be manipulated by deliberately restricting the amount of feed supplied during a given time, followed by a phase of overfeeding or compensation (Jobling et al., 1999). It has been observed that animals that undergo a period of growth depression due to a reduction or lack of food (quality and quantity) can reach the same size or weight corresponding to their age when the feeding conditions are favorable. This response, which tends to restore the original growth trajectory, is called compensatory growth (Ali et al., 2003). However, manipulation of feeding regimes can also influence production features that are important commercially, such as the increase in biomass, proportion of fat in the body, feed conversion ratio, fish size, and size variability (Sveier \& Lied, 1998). The size variability or size heterogeneity of a population is a common event among organisms of the same cohort. It can be interactive (competition) and non-interactive (genetic variation), due to biotic and abiotic factors (Kestemont et al., 2003), such as the initial heterogeneity, 
hierarchical behavior, high culture densities, and daily feeding ration. An increase in size heterogeneity has been observed during periods of restricted feeding because the growth rates of subordinate fish can be reduced due to the aggression of larger fish (Cutts et al., 1998; Gélineau et al., 1998; Joblin et al., 1999; Nicieza \& Metcalfe, 1999; Álvarez, 2011).

In the intensive culture of tilapia, studies that have assessed the effect of ration size have focused on evaluating: growth and feeding efficiency (Al-Ahmad et al., 1988; Papoutsoglou \& Voutsinos, 1988; Xie et al., 1997), feeding ration on size heterogeneity, harvesting time (Domínguez-May et al., 2011), and feeding ration size from an economic and environmental point of view (Poot-López et al., 2014).

About compensatory growth in tilapia, Wang et al. (2000) compared the growth of hybrids (Oreochromis mossambicus $\times$ O. niloticus) fed to satiety and starved for one, two and four weeks (before compensation to satiety). Only the fish that were deprived of food for a week managed to compensate growth with the treatment to satiety. Abdel-Hakim et al. (2009) developed an experiment in tanks, where they compared the growth and feed conversion ratio of tilapia hybrids (Oreochromis niloticus $\times O$. aureus) fed with diets to satiety and starved weekly for four months (one, two, and three days per week) and with a compensation stage (two months). The restricted treatments of one and two days, presented growth like the treatment to satiety when they were compensated, reducing feed consumption and production cost. However, in studies of compensatory growth in tilapia, few experiments have been performed using partially restricted rations in comparison with fish fed rations to satiety. Therefore, the present study aims to evaluate the biological indicators commonly applied in aquaculture (growth and feed conversion ratio) and analyze biometric aspects and the behavior of the size distribution when comparing restricted and compensated feeding rations.

\section{MATERIALS AND METHODS}

\section{Experimental design}

A randomized design was performed in the aquaculture facilities of the Department of Marine Resources at CINVESTAV Merida, divided into two stages: restricted stage (RS) and compensated stage (CS). In both experimental stages, balanced commercial feed $(32 \%$ protein) was offered.

Tilapia juveniles (reversed males) of the Chitralada line were used from a single clutch of fish (Grupo
Consultor Acuícola S.C.). The experiment was developed on two stages, restricted (RS) and compensated stage (CS), each stage lasted three weeks (six weeks in total). Three hundred juveniles of Nile tilapia Oreochromis niloticus (mean initial weight of $16.4 \pm 0.2 \mathrm{~g}$ ) were divided into three treatments, each treatment with three repetitions ( 25 fish per tank) and one control. The control group was fed four times a day to apparent satiation in both stages, where satiation is the maximum amount of feed that a fish can consume per unit time (10 min), thus avoiding waste (Goddard, 1996). In the RS, treatments were based on $100 \%$ (RS100), 80\% (RS80), and 60\% (RS60) of a feeding chart recommended by the manufacturer, respectively (Table 1). Feeding supplied was adjusted every 14 days as fish gain weight, following the feeding chart and their proportions; each ration was divided into four portions a day.

In the CS, the fishes of all treatments were fed with satiety rations, recording the weight feed consumed. The CS treatments were identified as CS100, CS80, CS60, and control group. At the end of each experimental stage, a total of 12 individuals per treatment were sacrificed to perform chemical analysis.

\section{Experimental system}

The experiments were carried out in a semi-open recirculation system, which included 12 self-cleaning fiberglass tanks with a capacity of $0.5 \mathrm{~m}^{-3}$, in addition to a container for decantation and complementary aeration. Tank maintenance consisted of feces daily removal using a siphon, and replacement of $25 \%$ of the water volume to avoid the accumulation of nitrogenous wastes (feces and unconsumed feed). The total water volume in the tanks was replaced once a week, and general cleaning was performed every 14 days to remove the biota established on the walls of the tanks.

Table 1. The feeding chart used to calculate restricted rations per Fish weight $(\approx 11 \mathrm{~g}$ intervals).

\begin{tabular}{lccc}
\hline & \multicolumn{3}{c}{ Restricted ration } \\
\cline { 2 - 4 } & RS100\% & RS80\% & RS60\% \\
\hline Fish weight (g) & \multicolumn{3}{c}{ Body weight (\%) } \\
\hline $12.1-22.9$ & 5.6 & 4.5 & 3.4 \\
$23.0-39.9$ & 4.7 & 3.8 & 2.8 \\
$40.0-50.0$ & 3.8 & 3.0 & 2.3 \\
$50.1-65.0$ & 3.8 & 3.0 & 2.3 \\
$65.1-90.0$ & 3.3 & 2.6 & 2.0 \\
$90.1-150$ & 2.8 & 2.3 & 1.7 \\
$150-200$ & 2.3 & 1.9 & 1.4 \\
$200-300$ & 2.2 & 1.7 & 1.3 \\
$300-500$ & 1.9 & 1.5 & 1.1 \\
\hline
\end{tabular}




\section{Indicators of growth, survival, and feeding}

The organisms were weighed every 14 days using an electronic balance with an accuracy of $0.01 \mathrm{~g}$. Fish growth was evaluated using the models suggested by Hepher (1988), Goddard (1996) and Halver \& Hardy (2002): individual weight gained $(\mathrm{g}),(\mathrm{WG}=$ average final weight - average initial weight); survival (\%), (S $=100$ (final number/initial number); and feed conversion ratio (FCR $=$ feed offered/weight gained).

\section{Size heterogeneity and proximal composition}

Size heterogeneity was evaluated with the coefficient of variation $(\mathrm{CV})$ of weight:

$$
\mathrm{CV}(\%)=(\sigma / \bar{x}) \times 100
$$

where: $\sigma$ is the standard deviation of the weights $(\mathrm{g})$ and $\bar{x}$ is the average weight (Bhujel, 2008).

At the end of each experimental stage, proximate analyses were performed to fish carcasses (three replicates) with standard methods (AOAC, 1990). The moisture content was determined using a drying oven at $36-48 \mathrm{~h}$ to $104^{\circ} \mathrm{C}$, depending on fish size and the crude protein content by using the Kjeldahl method $(\mathrm{N} \times 6.25)$. The lipid content was determined by the Soxhlet method, using petroleum ether as a solvent and ash by incineration of a pre-weighed sample in a silica crucible in a muffle furnace at $600^{\circ} \mathrm{C}$ for $6 \mathrm{~h}$.

\section{Water quality parameters}

The water quality parameters were measured and recorded weekly during the experiment. Dissolved oxygen concentrations and temperature were measured onsite twice a week with a YSI model 550A, whereas $\mathrm{pH}$ was determined using an Oakton Combo pH/EC/STS/SAL. A Hach DR/890 portable colorimeter was used to measure the ammonia nitrogen $\left(\mathrm{NH}_{3}{ }^{+}\right)$, nitrite $\left(\mathrm{NO}_{2}{ }^{-}\right)$, and nitrate $\left(\mathrm{NO}_{3}{ }^{-}\right)$.

\section{Statistical analysis}

At the end of each experimental stage, the results of weight gained, final weight, and the feed conversion ratio was compared using a one-way analysis of variance (ANOVA), with a confidence interval of $95 \%$ to test statistical differences among treatments (Bhujel, 2008). Besides, due to the initial weight of the fish in $\mathrm{CS}$, the final weight and weight gained was compared using a one-way analysis of covariance (ANCOVA). It was verified that both tests met the assumptions of normality and homogeneity of variance. The differences between the means were tested using Tukey's HSD test.

\section{RESULTS}

\section{Restricted stage (RS)}

Survival was $100 \%$ (excluding the individuals sacrificed for the other analysis). The weight gained, and final weight presented significant differences (ANOVA, $P<0.05$ ) between the four treatments; the RS60 ration presented the lowest final weight $(20.1 \pm$ $1.0 \mathrm{~g}$ ) and the ration control group gave the highest $(41.8 \pm 0.7 \mathrm{~g})$. The partial feed conversion ratio showed significant differences (ANOVA, $P<0.05$ ) between the control group and restricted rations (RS60, RS80, and RS100) (Table 2).

The final coefficient of variation $\left(\mathrm{CV}_{\mathrm{f}}\right)$ of $\mathrm{RS}$ increased when the restricted ration was higher until it reached the control group, except for the RS60, which was higher than for RS80 (Table 2); however, no significant differences were found between treatments.

According to the results of proximate composition, the fish carcasses RS60 showed moisture content significantly higher than the control group. Additionally, the control group had a higher percentage of protein compared with RS60 (ANOVA, $P<0.05$ ), but not with other rations. Lipid levels of RS60 and RS80 were significantly lower than those of the control group (ANOVA, $P<0.05$ ); however, the percentages of RS100 showed no differences with other treatments (ANOVA, $P>0.05$ ). The percentage of ash did not show significant differences among treatments (Table $3)$.

\section{Compensated stage (CS)}

Only one organism died throughout the CS, which corresponded to the control group (Table 4). The weight gained, and final weight did not present significant differences (ANCOVA, $P>0.05$ ) between the treatments CS80, CS100, and control group. However, the CS60 treatment did not manage compensatory growth concerning the control group (Table 4). The feed conversion ratio (FCR) of the control group was significantly higher than other treatments (ANOVA, $P<0.05$ ). The $\mathrm{CV}_{\mathrm{f}}$ values of $\mathrm{CS}$ did not present significant differences (ANOVA, $P>$ 0.05).

Proximate analysis of fish carcasses indicated that the moisture content was not a significantly different amount of treatment. The lipid level of CS60 was lower than the control group, but not when it was compared with the other rations. The crude protein of CS60 was significantly lower than those of CS80 (ANOVA, $P<$ 0.05); however, the percentages of CS80 showed no differences with other treatments (ANOVA, $P>0.05$ ). 
Table 2. Mean values \pm standard deviation of weight, feed conversion ratio (FCR), and coefficient of variation (CV) of juvenile tilapia fed with restricted rations (RS) and control group. Values with the same superscript numeral did not present significant differences, ANOVA $(P>0.05)$.

\begin{tabular}{|c|c|c|c|c|}
\hline & \multicolumn{4}{|c|}{ Restricted ration } \\
\hline & RS60\% & RS80\% & RS100\% & Control \\
\hline Survival (\%) & 100 & 100 & 100 & 98.55 \\
\hline eight (g) & $16.6 \pm 0.2^{\mathrm{a}}$ & $16.6 \pm 0.2^{\mathrm{a}}$ & $16.7 \pm 0.1^{\mathrm{a}}$ & $16.6 \pm 0.1^{\mathrm{a}}$ \\
\hline Final v & $36.7 \pm 0.9^{\mathrm{a}}$ & $46.8 \pm 1.1^{\mathrm{b}}$ & $52.4 \pm 1.7^{c}$ & $58.5 \pm 0.7^{\mathrm{d}}$ \\
\hline Weight gained $(\mathrm{g})$ & $20.1 \pm 1.0^{\mathrm{a}}$ & $30.1 \pm 1.2^{\mathrm{b}}$ & $35.6 \pm 1.7^{c}$ & $41.8 \pm 0.6^{\mathrm{d}}$ \\
\hline FCR & $1.30 \pm 0.1^{\mathrm{a}}$ & $1.25 \pm 0.0^{\mathrm{a}}$ & $1.29 \pm 0.0^{\mathrm{a}}$ & $1.39 \pm 0.0^{\mathrm{b}}$ \\
\hline $\mathrm{CV}_{\mathrm{i}}(\%)$ & $10.6 \pm 0.5^{\mathrm{a}}$ & $11.6 \pm 3.2^{\mathrm{a}}$ & $10.8 \pm 1.2^{\mathrm{a}}$ & $10.5 \pm 0.5^{\mathrm{a}}$ \\
\hline $\mathrm{CV}_{\mathrm{f}}(\%)$ & $26.5 \pm 1.5^{\mathrm{a}}$ & $26.1 \pm 3.7^{\mathrm{a}}$ & $29.8 \pm 0.7^{\mathrm{a}}$ & $32.8 \pm 3.3^{\mathrm{a}}$ \\
\hline
\end{tabular}

Table 3. Whole-body proximate composition of Nile tilapia (Oreochromis niloticus) at the end of the restricted rations (RS), and control group. Values with the same superscript letters did not present significant differences, ANOVA $(P>$ $0.05)$.

\begin{tabular}{lrrrrr}
\hline \multirow{2}{*}{ \% Wet weight } & \multicolumn{5}{c}{ Restricted ration } \\
\cline { 2 - 6 } & \multicolumn{1}{c}{ Initial } & \multicolumn{1}{c}{ RS60\% } & \multicolumn{1}{c}{ RS80\% } & \multicolumn{1}{c}{ RS100\% } & \multicolumn{1}{c}{ Control } \\
\hline Moisture & $67.2 \pm 0.5$ & $64.1 \pm 1.2^{\mathrm{a}}$ & $62.1 \pm 0.3^{\mathrm{a}, \mathrm{b}}$ & $60.6 \pm 2.4^{\mathrm{a}, \mathrm{b}}$ & $56.9 \pm 1.3^{\mathrm{b}}$ \\
Lipid & $9.0 \pm 0.1$ & $9.5 \pm 0.4^{\mathrm{a}}$ & $9.8 \pm 0.4^{\mathrm{a}}$ & $10.2 \pm 0.3^{\mathrm{a}, \mathrm{b}}$ & $11.6 \pm 0.5^{\mathrm{b}}$ \\
Ash & $3.8 \pm 0.2$ & $4.7 \pm 0.0^{\mathrm{a}}$ & $4.5 \pm 0.2^{\mathrm{a}}$ & $4.3 \pm 0.5^{\mathrm{a}}$ & $4.2 \pm 0.0^{\mathrm{a}}$ \\
Crude protein & $19.9 \pm 0.8$ & $21.7 \pm 0.8^{\mathrm{a}}$ & $23.6 \pm 0.2^{\mathrm{a}, \mathrm{b}}$ & $24.8 \pm 1.6^{\mathrm{a}, \mathrm{b}}$ & $27.3 \pm 0.8^{\mathrm{b}}$ \\
\hline
\end{tabular}

Table 4. Mean values \pm standard deviation of weight, feed conversion ratio (FCR), and coefficient of variation (CV) of juvenile tilapia fed with restricted rations compensated rations (CS) and control group. Values with the same superscript numeral did not present significant differences ANOVA $(P>0.05)$, *ANCOVA $(P>0.05)$.

\begin{tabular}{lcccc}
\hline \multirow{2}{*}{ Mean values } & \multicolumn{4}{c}{ Compensated rations } \\
\cline { 2 - 5 } & CS60\% & CS80\% & CS100\% & Control \\
\hline Survival (\%) & 100 & 100 & 100 & 98.55 \\
Initial weight $(\mathrm{g})$ & $36.7 \pm 0.9^{\mathrm{a}}$ & $46.8 \pm 1.1^{\mathrm{b}}$ & $52.4 \pm 1.7^{\mathrm{c}}$ & $58.5 \pm 0.7^{\mathrm{d}}$ \\
${\text { Final weight }(\mathrm{g})^{*}}_{\left.\text {Weight gained }^{\mathrm{g}}\right)^{*}}$ & $98.2 \pm 10.0^{\mathrm{a}}$ & $122.3 \pm 12.5^{\mathrm{a}, \mathrm{b}}$ & $131.3 \pm 9.9^{\mathrm{b}}$ & $132.8 \pm 11.1^{\mathrm{b}}$ \\
FCR $^{\mathrm{C}}$ & $1.67 \pm 0.6^{\mathrm{a}}(\%)$ & $75.5 \pm 12.0^{\mathrm{a}}$ & $78.9 \pm 9.1^{\mathrm{a}}$ & $74.3 \pm 10.6^{\mathrm{a}}$ \\
$\mathrm{CV}_{\mathrm{f}}(\%)$ & $26.5 \pm 1.5^{\mathrm{a}}$ & $26.13 \pm 0.0^{\mathrm{a}} \mathrm{b}$ & $1.62 \pm 0.0^{\mathrm{a}}$ & $1.86 \pm 0.1^{\mathrm{b}}$ \\
\hline
\end{tabular}

The ash percentage of CS100 and the control group showed significant differences with other treatments (Table 5)

\section{Water quality parameters}

The water quality parameters were maintained within acceptable ranges, as shown in Table 6 . The average water temperature for RS was $27.07 \pm 0.97^{\circ} \mathrm{C}$, with a minimum of $25.0^{\circ} \mathrm{C}$ and a maximum of $28.1^{\circ} \mathrm{C}$. However, in CS, the average water temperature was $25.8 \pm 1.88^{\circ} \mathrm{C}$, with a minimum of $22.3^{\circ} \mathrm{C}$ and a maximum of $28.1^{\circ} \mathrm{C}$.

\section{DISCUSSION}

The feed is the main component in fish growth; the amount and quality of food directly influence biomass production and feed conversion (Brett, 1979). Inducing compensatory growth in fish is of considerable importance in aquaculture since it can offer advantages such as increased growth rates, a reduction in feed conversion ratio, and a consequent decrease in nitrogenous waste (Tian \& Qin, 2004). However, disadvantages have been reported in its implementation, particularly effects on size heterogeneity and increases in the aggressiveness of fish when food is limited (Moutou et al., 1998) or when it is abundant, 
Table 5. Whole-body proximate composition of Nile tilapia (Oreochromis niloticus) at the end of the compensated stage (CS), and control group. Values with the same superscript letters did not present significant differences, ANOVA $(P>$ $0.05)$.

\begin{tabular}{lrrrr}
\hline \multirow{2}{*}{$\%$ Wet weight } & \multicolumn{4}{c}{ Compensated rations } \\
\cline { 2 - 5 } & \multicolumn{1}{c}{ CS60\% } & \multicolumn{1}{c}{ CS80\% } & CS100\% & \multicolumn{1}{c}{ Control } \\
\hline Moisture & $57.3 \pm 0.92^{\mathrm{a}}$ & $51.2 \pm 1.1^{\mathrm{a}}$ & $51.4 \pm 2.0$ & $51.3 \pm 2.0^{\mathrm{a}}$ \\
Lipid & $9.5 \pm 0.39^{\mathrm{a}}$ & $11.47 \pm 0.5^{\mathrm{a}}$ & $12.5 \pm 1.5^{\mathrm{a}, \mathrm{b}}$ & $13.1 \pm 0.6^{\mathrm{b}}$ \\
Ash & $4.4 \pm 0.01^{\mathrm{a}}$ & $4.8 \pm 0.0^{\mathrm{a}}$ & $4.9 \pm 0.2^{\mathrm{b}}$ & $5.2 \pm 0.0^{\mathrm{b}}$ \\
Crude protein & $28.7 \pm 0.53^{\mathrm{a}}$ & $32.7 \pm 0.6^{\mathrm{b}}$ & $31.2 \pm 0.4^{\mathrm{a}, \mathrm{b}}$ & $30.5 \pm 1.4^{\mathrm{a}, \mathrm{b}}$ \\
\hline
\end{tabular}

Table 6. Mean values \pm standard deviation of physical and chemical properties of the water in both experimental stages, restricted rations (RS), and compensated stage (CS).

\begin{tabular}{lcc}
\hline Parameters & RS & CS \\
\hline $\mathrm{pH}$ & $8.3 \pm 0.60$ & $8.5 \pm 0.25$ \\
$\mathrm{DO}\left(\mathrm{mg} \mathrm{L}^{-1}\right)$ & $6.8 \pm 0.42$ & $6.9 \pm 0.42$ \\
$\mathrm{TAN}\left(\mathrm{mg} \mathrm{L}^{-1}\right)$ & $0.1 \pm 0.117$ & $0.1 \pm 0.046$ \\
$\mathrm{NO}_{2}\left(\mathrm{mg} \mathrm{L}^{-1}\right)$ & $0.08 \pm 0.012$ & $0.03 \pm 0.019$ \\
$\mathrm{NO}_{3}\left(\mathrm{mg} \mathrm{L}^{-1}\right)$ & $3.9 \pm 1.46$ & $4.19 \pm 0.422$ \\
\hline
\end{tabular}

due to the hyperphagia characteristic (Alvarez, 2011). Karplus (2005) summarized this population condition in four important aspects: direct competition for food, social stress, increased motor activity, and dominance cost. Localized food access is often considered an important factor responsible for the retarded growth of subordinate fish in the cohort, increasing size heterogeneity (Gélineau et al., 1998).

In the present study, food was supplied by hand, distributing it homogenously. The values of weight gained from RS presented a logical response in accordance with the amount of food provided, being the control group, which showed the highest growth, but with a higher feed conversion ratio. Significant differences were observed in weight gain for all the treatments when comparing the decrease in this parameter and the percentage of feed consumed (\% BW) by the fish of the restricted treatment. The RS60, RS80, and RS100 treatments presented a weight gain of 47.9, 72.1 , and $85.2 \%$, respectively, and the percentage of feed consumed was 53.6, 71.7, and $82.5 \%$, in comparison with the control group (100\%) for both parameters (Table 2). Later, this might indicate that the fish in the RS100 treatment used the supplied feed more efficiently since when faced with a $17.5 \%$ reduction in food, the weight gained decreased $14.8 \%$, even though the RS80 treatment presented the lowest FCR (Table 2). Studies on mrigal carp Cirrhinus cirrhosus showed that the most efficient rations were below the ration to satiety (Khan et al., 2004), as observed in the present study.

At the end of RS, the percentage of moisture was significantly higher in fishes of RS60, which were subject to greater food restriction. Tissue hydration has been observed in fish that suffering periods of starvation as a physiological response to prevent decreased muscle mass or even maintaining the wet body mass during fasting (Jobling, 1980; Miglavs \& Jobling, 1989). On the other hand, when the growth rates of fish are reduced, a decrease occurs in the renewal of tissue, and the body fat deposits are more affected than protein (Hornick et al., 2000). We observed the same situation with tilapias of RS60, where a significant decrease in the percentage of lipid and protein relative to the control group was found. However, the protein percentages were lower than those of lipids (Table 3).

In CS of the experiment, the values of weight gain of organisms from the compensated treatments did not present significant differences (ANCOVA, $P>0.05$ ) respect to the control group. However, CS60 reached only $82.8 \%$ of the weight gained respect to the control group, unlike CS100, which was $6.2 \%$ upper regarding weight gain of the control group. Although the average daily ration of CS60, CS80, and CS100 (previously restricted rations) were $22.11,12.87$, and $0.5 \%$ upper regarding the control group, respectively, no significant differences were observed in the FCR of all treatments. Furthermore, no significant effects were presented in the $\mathrm{CV}_{\mathrm{f}}$.

At the end of CS, the moisture content of CS60 had no significant difference with other treatments, due to compensatory ration. However, the percentage of lipids failed to recover, presenting lower values than the control group, as it has been previously observed with fish that underwent low food ration (Tian \& Qin, 2004). Meanwhile, the protein percentages of CS60 were significantly lower than those of CS80.

Global analysis of the experiment showed that the restricted rations equal to or greater than $80 \%$ of the 
quota recommended by the feeding tables (100\%), could present compensatory growth similar to that of the rations to satiety, significantly reducing the FCR. The above can be achieved because the quotas of the restricted treatments were sub-lethal. The fish were able to compensate growth, except for the ration to $60 \%$ (RS60), which provides evidence that the accelerated growth and growth rates of the fish can be regulated based on prior food restriction (Ali et al., 2003).

Although the $\mathrm{CV}_{\mathrm{f}}$ of the four rations did not present significant differences, there is an apparent increase in this indicator in the control group (Tables 2 and 4), where several subordinate fish did not attain the weight necessary to allow them to compete for the available food. In species such as salmon, the aggressiveness increase of larger fish concerning those that are smaller has been detected, even when the diet is not restricted (Nicieza \& Metcalfe, 1999). Experiment by Onders et al. (2008) showed that excessive feeding does not affect the variability of individual sizes in the paddlefish. Recently these authors presented the same results with the classification of sizes and feeding frequency.

In tilapia studies, rations to satiety increase the weight dispersion of fish, reducing the uniformity of the final product (Domínguez-May et al., 2011), also observed in the present study, corroborated by the standard deviation generated based on the data from the two stages of the experiment (Tables 2 and 4). It is desirable, from the market point of view, that the harvested fish to be of uniform size (Zhou et al., 2003). A convenient way of helping to control this is through feeding management, despite the natural variation of individual sizes, widely questioned in fish farming.

Feeding strategies can be adapted to minimize the environmental impact of aquaculture, production costs, or the quality of the fish (Bavčević et al., 2010; PootLópez et al., 2014). If maximizing fish weight is important, the optimum feeding strategies should involve a slight reduction in food, followed by a short period of intensive feeding, which allows them to increase their length close to the maximum and increase the condition factor and final weight (Bavčević et al., 2010). It shows that the optimizing feeding regimes during the growth process of fish could reduce the costs of feeding, without slowing growth, increasing quality and profits, which could ensure the future success of aquaculture development and management (Oh et al., 2013).

In conclusion, the management of feeding regimes during the growth process of fish can reduce feed consumption and its costs. They are maintaining a similar growth and without differences to that recommended by feed producers. The $\mathrm{R} 80 \%$ and R100\% treatments had better use of the feed supplied by 72.1 and $85.2 \%$, compared to the control group (satiety). This study supports the hypothesis when the feed is restricted, fish use to moisturize their tissue to compensate for the muscle loss until they receive more food. However, when the feed restriction levels are too high, the weight gain, lipid, and protein levels do not recover as they were before. Compensatory feeding strategies can help improve different productive indicators in Nile tilapia (O. niloticus) culture.

\section{REFERENCES}

Abdel-Hakim, N.F., State, HA, Al-Azab, A.A. \& ElKholy, F. 2009. Effect of feeding regimes on growth performance of juvenile hybrid tilapia (Oreochromis niloticus $\times$ Oreochromis aureus). World Journal of Agricultural Sciences, 5(1): 49-54.

Al-Ahmad, T.A., Ridha, M. \& Al-Ahmad, A.A. 1988. Production and feed ration of the tilapia Oreochromis spilarus in seawater. Aquaculture, 73: 111-118.

Ali, M., Nicieza, A. \& Wootton, J.R. 2003. Compensatory growth in fishes: a response to growth depression. Fish and Fisheries, 4: 147-190.

Álvarez, D. 2011. The effects of compensatory growth on fish behaviour. In: Farrell, A.P. (Ed.). Encyclopedia of fish physiology: from genome to environment. Academic Press, San Diego, pp. 752-757.

Association of Official Analytical Chemists (AOAC). 1990. Association of Official Analytical Chemists (CD-ROM). Official methods of analysis of the Association of Official Analytical Chemists, Arlington.

Bavčević, L., Klanjšček, T., Karamarko, V., Aničić, I. \& Legović, T. 2010. Compensatory growth in gilthead seabream (Sparus aurata) compensates weight but not length. Aquaculture, 301: 57-63.

Bhujel, R.C. 2008. Statistics for aquaculture. WileyBlackwell, Singapore.

Booth, M.A., Tucker, B.J., Allan, G.L. \& Stewart-Fielder, D. 2008. Effect of feeding regime and fish size on weight gain, feed intake, and gastric evacuation in juvenile Australian snapper Pagrus auratus. Aquaculture, 282: 104-110.

Borski, R.J., Bolivar, R.B., Jimenez, E.B.T., Sayco, R.M.V., Arueza, R.L.B., Stark, C.R. \& Ferket, P.R. 2011. Fishmeal-free diets improve the cost effectiveness of culturing Nile tilapia (Oreochromis niloticus, L.) in ponds under an alternate day feeding strategy. In: Liping, L. \& Fitzsimmons, K. (Eds.). Proceedings of the Ninth International Symposium on Tilapia in Aquaculture. Shanghai, China. pp. 95-101.

Brett, J.R. 1979. Environmental factors and growth. In: Hoar, W.S. \& Randall, D.J. (Eds.). Fish physiology. 
Bioenergetic and growth. Academic Press, New York, pp. 599-675.

Bureau, D.P., Hua, K. \& Cho, C.Y. 2006. Effect of feeding level on growth and nutrient deposition in rainbow trout (Oncorhynchus mykiss Walbaum) growing from 150 to $600 \mathrm{~g}$. Aquaculture Research, 37: 1090-1098.

Cutts, C.J., Metcalfe, N.B. \& Taylor, A.C. 1998. Aggression and growth depression in juvenile Atlantic salmon: the consequences of individual variation in standard metabolic rate. Journal of Fish Biology, 52: 1026-1037.

Domínguez-May, R., Hernández, J.M, Gasca-Leyva, E. \& Poot-López, G.R. 2011. Effect of ration and size heterogeneity on harvest time: tilapia culture in Yucatan, Mexico. Aquaculture Economics \& Management, 15: 278-301.

Gélineau, A., Corraze, G. \& Boujard, T. 1998. Effects of restricted ration, time-restricted access, and reward level on voluntary food intake, growth, and growth heterogeneity of rainbow trout (Oncorhynchus mykiss) fed on demand with self-feeder. Aquaculture, 167: 247-258.

Goddard, S. 1996. Feed management in intensive aquaculture. Chapman and Hall, New York.

Guimarães, I.G., Pezzato, L.E., Barros, M.M. \& Tachibana, L. 2008. Nutrient digestibility of cereal grain products and by-products in extruded diets for Nile tilapia. Journal of the World Aquaculture Society, 39(6): 781-789.

Halver, J.E. \& Hardy, R.W. 2002. Fish nutrition. Academic Press, New York.

Hepher, B. 1988. Nutrition of pond fishes. Cambridge University Press, London.

Hornick, J.L., Van Eenaemea, C., Gérard, O., Dufrasne, I. \& Istasse, L. 2000. Mechanisms of reduced and compensatory growth. Domestic Animal Endocrinology, 19: 121-132.

Jobling, M. 1980. Effects of starvation on proximate chemical composition and energy utilization of plaice, Pleuronectes platessa L. Journal of Fish Biology, 17: 325-334.

Jobling, M., Koskela, J. \& Winberg, S. 1999. Feeding and growth of whitefish fed restricted and abundant rations: influences on growth heterogeneity and brain serotonergic activity. Journal of Fish Biology, 54: 437449.

Karplus, I. 2005. Social control of growth in Macrobrachium rosenbergii (De Man): a review and prospects for future research. Aquaculture Research, 36: 238-254.

Kestemont, P., Jourdan, S., Houbart, M., Mélard, C., Paspatis, M., Fontaine, P., De Cuvier, A., Kentouri, M. \& Baras, E. 2003. Size heterogeneity, cannibalism, and competition in cultured predatory fish larvae: biotic and abiotic influences. Aquaculture, 227: 333356.

Khan, M.A., Ahmed, I. \& Abidi, S.F. 2004. Effect of ration size on growth, conversion efficiency, and body composition of fingerling mrigal, Cirrhinus mrigala (Hamilton). Aquaculture Nutrition, 10: 47-53.

Miglavs, I. \& Jobling, M. 1989. The effects of feeding regime on proximate body composition and patterns of energy deposition in juvenile Arctic charr, Salvelinus alpinus. Journal of Fish Biology, 35: 1-11.

Moutou, K.A., Mccarthy, I.D. \& Houlihan, D.F. 1998. The effect of ration level and social rank on the development of fin damage in juvenile rainbow trout. Journal of Fish Biology, 52: 756-770.

Nicieza, A.G. \& Metcalfe, N.B. 1999. Costs of rapid growth: the risk of aggression is higher for fastgrowing salmon. Functional Ecology, 13: 793-800.

Oh, S.Y., Kim, M.S., Kwon, J.Y. \& Venmathi-Maran, B.A. 2013. Effects of feed restriction to enhance the profitable farming of blackhead seabream Acanthopagrus schlegelii schlegelii in sea cages. Ocean Science Journal, 48(3): 263-268.

Onders, R.J., Mims, S.D. \& Dasgupta, S. 2008. Growth, condition, and size distribution of paddle fish, Polyodons pathula, juveniles reared in ponds at three densities. Journal of the World Aquaculture Society, 39(4): 565-571.

Papoutsoglou, S.E. \& Voutsinos, G.E. 1988. Influence of feeding level on growth rate of Tilapia aureus (Steindachner) reared in closed circulated system. Journal of Aquaculture and Fisheries Management, 19: 291-298.

Poot-López, G.R., Hernández, J.M. \& Gasca-Leyva, E. 2014. Analysis of ration size in Nile tilapia production: economics and environmental implications. Aquaculture, 420-421: 198-205.

Sveier, H. \& Lied, E. 1998. The effects of feeding regime on growth, feed utilization, and weight dispersion in large Atlantic salmon (Salmo salar) reared in seawater. Aquaculture, 165: 333-345.

Talbot, C., Corneillie, S. \& Korsùen, Ø. 1999. Pattern of feed intake in four species of fish under commercial farming conditions: implications for feeding management. Aquaculture Research, 30: 509-518.

Tian, X. \& Qin, J.G. 2004. Effects of previous ration restriction on compensatory growth in barramundi Lates calcarifer. Aquaculture, 235: 273-283.

Wang, Y., Cui, Y., Yang, Y. \& Cai, F. 2000. Compensatory growth in hybrid tilapia, Oreochromis mossambicus $\times O$. niloticus, reared in seawater. Aquaculture, 189: 101-108.

Xie, S., Cui, Y., Yang, Y. \& Liu, J. 1997. Energy budget of Nile tilapia (Oreochromis niloticus) in relation to ration size. Aquaculture, 154: 57-58. 
Zhou, Z., Cui, Y., Xie, S., Zhu, X., Lei, W., Xue, M. \& Yang, Y. 2003. Effect of feeding frequency on growth, feed utilization, and size variation of juvenile gibel carp (Carassius auratus gibelio). Journal of Applied Ichthyology, 19: 244-249.

Received: 11 November 2019; Accepted: 10 February 2020 